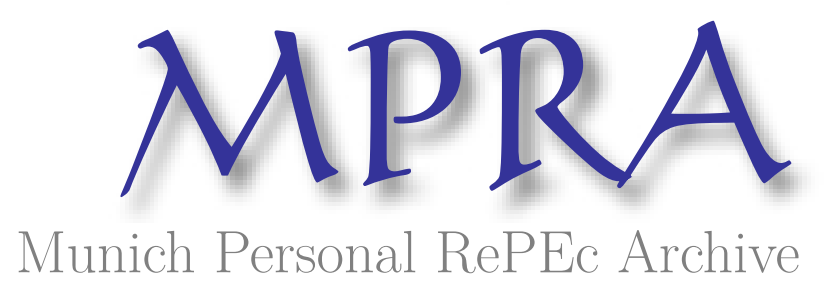

Socioeconomic Cleavages between Workers from New Member States and Host-country Labour Forces in the EU during the Great Recession

Guzi, Martin and Kahanec, Martin

Masaryk University, CELSI, IZA, Central European University

2015

Online at https://mpra.ub.uni-muenchen.de/74978/

MPRA Paper No. 74978, posted 17 Dec 2019 14:53 UTC 
Socioeconomic cleavages between workers from new member states and host- country labour forces in the EU during the Great Recession1

\section{Martin Kahanec}

Central European University, CELSI, and IZA

\section{Martin Guzi}

Masaryk University, CELSI, and IZA

(Citation: Guzi, M, Kahanec M. 2015. Socioeconomic Cleavages between Workers from New Member States and Host-country Labour Forces in the EU during the Great Recession. In: Bernaciak, M. (ed.) Market Expansion and Social Dumping in Europe. London: Routledge)

Accepted version: October 2014

\footnotetext{
${ }^{1}$ This study was commissioned by the European Trade Union Institute, Brussels, whose support is gratefully acknowledged. We thank Magdalena Bernaciak for helpful comments and suggestions. Any remaining errors are the responsibility of the authors. Corresponding author: Martin Kahanec, Central European University, Budapest, Hungary, Email: KahanecM@spp.ceu.edu
} 


\section{Summary}

Although there is consensus in the literature that immigrants generally adjust in terms of their labour market status the more time they spend in the host country (Chiswick, 1978; Borjas, 1985; Kahanec and Zaiceva, 2009), the economic crisis that struck Europe shortly after the 2004 and 2007 EU enlargements, referred to in this chapter as the Great Recession, may have stalled or even reversed such adjustment processes. In addition, the significant increase in east-west mobility may have changed the nature of labour market competition in the receiving labour markets or have had consequences for the process of adjustment. East-west mobility within the EU may have interacted with inflows of non-EU migrants, resulting in heightened competition in the labour market (Biavaschi and Zimmermann, 2014; Marchetti et al., 2014). These effects could vary across different aspects of the market, such as labour market participation, employment and its quality, or the incidence of self-employment. This chapter provides a comprehensive perspective on labour market cleavages between migrants from new EU member states and natives in old EU member states for the period following the EU enlargements of 2004 and 2007 and during the Great Recession. It thus sheds light on how post-enlargement mobility, interacting with the consequences of the downturn, has affected the social fabric in the receiving countries. The chapter is structured as follows. In the first section, we discuss the main patterns and factors of immigrant integration in Europe. We then focus on post-enlargement migration and the integration of migrants from new EU member states in the old EU member states before and during the crisis. The methodology for measuring immigrant-native gaps and the data we use are outlined in the following sections. Finally, we measure immigrant-native labour market gaps, distinguishing between the part attributable to differences in the characteristics of the two groups and the cleavages resulting from unobservable factors. 


\section{Introduction}

The 2004 and 2007 EU enlargements led to the relocation, over the period 2004-2010, of about three million workers from the new EU member states to the old. The free mobility of workers in the enlarged EU provided a larger set of possibilities for its citizens and improved the allocative efficiency of EU labour markets (Kahanec and Zimmermann, 2010). The receiving countries gained additional 'hands and brains' while generally not being affected in terms of natives' aggregate wages or employment (Kahanec, 2013); the sending countries, in turn, were relieved of labour slack and benefitted from remittances. 'Brain drain' has been a potential risk for the sending countries, but the literature actually points at the possibility of 'brain gain', which may occur when migrants return to their home countries with additional skills acquired abroad or when the home population invests more in education in expectation of higher returns due to the possibility of utilizing skills more freely abroad (see Zaiceva and Zimmerman, 2016). Similarly, although the downskilling into jobs below a worker's qualifications that characterizes much of post-enlargement migration appears undesirable, it is unclear whether real inefficiencies vis-à-vis feasible counterfactual scenarios have materialized (Kahanec, 2013). ${ }^{2}$

Against this generally positive perspective, there are some fears that post-enlargement migration has created socioeconomic cleavages between workers from new EU member states and the host labor force in the receiving countries in areas such as pay, access to employment and/or employment quality. ${ }^{3}$ Such cleavages could -either directly or as a side effect undermine economic and social standards in the receiving countries. The effects of immigration, then, might not immediately concern the wages or employment of natives, but rather materialize as persistent immigrant-native gaps in labour market outcomes, with potentially detrimental effects for the social fabric and cohesion of the receiving labour markets.

\footnotetext{
${ }^{2}$ To illustrate the logic, it may appear inefficient for a university-educated engineer to work as a receptionist, but this becomes less obvious if his/her only alternative in the home country would have been unemployment or inactivity.

${ }^{3}$ The term 'native' refers to the resident population in an old EU member state not originating from new EU member states. It does not imply nativity in the respective country.
} 
In this chapter, we use EU-wide micro-level datasets from Eurostat to empirically document labour market gaps between domestic labour forces and migrants from new EU member states. We distinguish between two origins of immigrant-native labour market gaps. First, we look at the part of the observed raw gaps that can be explained by differences in the characteristics of immigrant and native populations. Such 'explained' gaps arise due to factors determined outside of the receiving labour market, including gaps in population characteristics between receiving and sending countries, the characteristics of migrants who decided to move from new EU member states, and immigrant-native differences in patterns of human capital acquisition in the receiving country. ${ }^{4}$ These kind of gaps could lead to immigrant-native inequalities and may call for policies that would mitigate problematic cleavages and provide for a cohesive and mutually beneficial coexistence between diverse populations. On their own, however, their existence does not indicate unequal treatment or differences in behaviour of otherwise equal immigrants and natives in the labour market.

Second, we measure gaps that are not explained by differences in characteristics between immigrant and native populations. Cleavages defined and measured in this way may result from differences in individual preferences, social or ethnic capital, discrimination or other unobserved variables. The existence of unexplained gaps may be related to the segmentation of migrants into jobs of lower social or economic status. This may occur, for example, (i) as a temporary phenomenon related to adjustment to the demand for skills specific to the host country; (ii) as a consequence of processes outside migrants' control such as discrimination; or (iii) as an outcome of choices made by migrants as individuals or collectivities. As an example of choice-driven segmentation, some temporary migrants such as nurses may find it unprofitable - given the short time horizon over which the returns can be reaped - to invest in country-specific skills such as the language of the host country and may thus take up jobs below their formal qualification (e.g., domestic care or service activities), possibly with longer working hours (Kahanec and Shields, 2013).

\footnotetext{
${ }^{4}$ It is, of course, possible that different labour markets attract different types of migrants, or differently affect the prospects of migrants and natives for acquiring human capital. Labour market attributes may thus play an indirect role in the human-capital and other characteristics of the native and immigrant populations.
} 
Likewise, unexplained gaps in labour market outcomes between natives and immigrants may also signify strategic behaviour on the part of immigrant workers or the companies employing them aimed at reducing the costs of migrant labour as a consequence of any unobserved disadvantages or vulnerabilities migrant workers might face. In such circumstances, migrant workers may end up working for substandard remuneration or under substandard working conditions and, compared to observably similar natives, might not be integrated into the host country's social systems, work safety standards or collective bargaining agreements - a situation defined in this volume as social dumping. In regard to remuneration, for example, migrant workers might be willing to accept working for less than what is normally paid to observably similar natives (with similar qualifications, occupation and other characteristics) if it gives them a competitive advantage or, perhaps more accurately, compensates for some unobserved disadvantage (also see Krings et al., this volume). All in all, then, unexplained gaps signify different treatment or behaviour of observationally equal immigrant and native populations in the labour market and signal social cleavages arising as a consequence of the functioning of the labour market. A policy intervention aimed at the reduction of such cleavages would therefore need to change the way in which immigrants and natives interact in the host-country labour market. ${ }^{5}$

Although there is consensus in the literature that immigrants generally adjust in terms of their labour market status the more time they spend in the host country (Chiswick, 1978; Borjas, 1985; Kahanec and Zaiceva, 2009), the economic crisis that struck Europe shortly after the 2004 and 2007 EU enlargements, referred to in this chapter as the Great Recession, might have stalled or even reversed such adjustment processes. Additionally, the significant increase in east-west mobility may have changed the nature of labour market competition in the receiving labour markets or have had consequences for the process of adjustment. East-west mobility within the EU might have interacted with inflows of non-EU migrants, resulting in heightened competition on the labour market (Biavaschi and Zimmermann, 2014; Marchetti, Piazzalunga and Venturini, 2014). These effects could vary across different aspects of the market, such as labour market participation, employment and its quality, or the incidence of self-employment.

\footnotetext{
${ }^{5}$ Certainly, explained gaps may result from unequal treatment outside of the labor market, and unexplained gaps may through workers' expectations and subsequent decisions (for example to invest less in own human capital in case of a negative unexplained gap) engender explained gaps.
} 
This chapter provides a comprehensive perspective on labour market cleavages between migrants from new EU member states and natives in old EU member states for the period following the EU enlargements of 2004 and 2007 and during the Great Recession. It thus sheds light on how post-enlargement mobility, interacting with the consequences of the downturn, has affected the social fabric in the receiving countries. The chapter is structured as follows. In the first section, we discuss the main patterns and factors of immigrant integration in Europe. We then focus on post-enlargement migration and the integration of migrants from new EU member states in the old EU member states before and during the crisis. The methodology for measuring immigrant-native gaps and the data we use are outlined in the following sections. Finally, we measure immigrant-native labour market gaps, distinguishing between the part attributable to differences in the characteristics of the two groups and the cleavages resulting from unobservable factors. Brief conclusions follow.

\section{Migrants and natives in European labour markets}

The literature on migration and immigrant integration reports significant differences in the labour market outcomes of immigrants and natives, which may fade away, however, with immigrants' tenure in the host country (Kahanec and Zaiceva, 2009). Dustmann and Frattini (2011) investigate the labour market performance of EU and non-EU immigrants in Belgium, Germany, Finland, France and Italy. Using the 2009 wave of the EU Labour Force Survey (EU-LFS), the authors find that immigrant earnings are located at the bottom of the overall earnings distribution. They show that around $75 \%$ of migrant households from new EU member states have earnings below the median income of native households. After controlling for demographic characteristics such as gender, age, education and occupation, the probability of being at the bottom of the earnings profile remains significantly higher for EU and non-EU migrants than for natives in Belgium, France and Italy.

Some of the theoretical explanations for the differences between immigrants and comparable natives include those based on the market value of the education acquired in different sending countries, the lack of country-specific skills such as language and/or knowledge of the receiving countries' labour market institutions, precarious employment, spatial segregation, 
institutional factors and various forms of discrimination (Huber et al., 2010; De la Rica, Glitz and Ortega, 2015). Language skills, for example, contribute positively to immigrants' human capital and increase their productivity in the labour market. In addition, the acquisition of language fosters social and economic integration. The relevance of language may be less significant for high-skilled workers, who are more likely to work in positions with English rather than the local language as the working language. It might also be, however, that immigrants, even those who are less skilled, work in ethnic enclaves and communicate in their own language at work. The link between language proficiency and productivity has been empirically substantiated by several studies. For Germany, Dustmann and van Soest (2002) use a panel data analysis to show that a good command of the German language is associated with a $10 \%$ wage premium among migrants. For Spain, Amuedo-Dorantes and de la Rica (2007) report that Latin American immigrants perform better in the labour market than immigrants from non-Spanish-speaking countries, thus supporting the idea that language is an important determinant of employment and earnings gaps. Entorf and Minoui (2005) provide interesting evidence regarding the importance of language in European countries. The authors observe that students with foreign parents and the foreign language spoken at home underperform relative to their native counterparts in the PISA evaluation. The educational disadvantage of immigrant children can translate into a disadvantage on the labour market later in life.

Immigrants appear to be disadvantaged relative to natives also in terms of their employment probabilities and occupational distribution. Dustmann and Frattini (2011) investigate the labour market performance of immigrant workers from other EU countries using a pooled sample of EU-LFS surveys from 2007 to 2009. The authors show that even if immigrants and natives lived in the same areas and had identical demographic characteristics, immigrants would still have lower employment probabilities than natives in all countries except for Greece, where the conditional difference was found to be close to zero. The authors further measure the degree of segmentation of immigrants into particular occupations. Controlling for workers' age, gender, education and region of residence, they find that in most countries EU immigrants work in less skilled occupations relative to their native counterparts. Only in Belgium, Finland, Ireland and the Netherlands does the occupational disadvantage between natives and EU immigrants disappear. 
The labour market situation of migrants also depends on the level of their formal education. Huber et al. (2010) propose that high-skilled migrants are more vulnerable and face higher unemployment risks than low-skilled migrants when it comes to finding employment on arrival in a new country. Low-skilled migrants have lower chances that any given job offered to them is below their qualification, so ultimately more job offers are acceptable to them compared to highly skilled migrants. A conditional analysis based on EU-LFS data from 2006-2007 confirms the hypothesis that high-skilled migrant workers have lower probabilities of employment compared to less skilled migrants; this outcome holds generally for migrants across the origins distinguished in the survey. The authors further confirm that high- and medium-skilled migrants have a significantly higher probability of being overqualified than natives, conditional on gender, age and sector of employment. Migrants from the EU-12 exhibit the highest probability of over-qualification in employment, while the probability of over-qualification is significantly lower for migrants born in the EU-15. ${ }^{6}$

Dustmann and Frattini (2011) show that the labour market performance of immigrants improves with time spent in the host country. Similarly, Huber et al. (2010) show that the probability of employment of the foreign born of all skill levels increases with the duration of their stay. These findings are corroborated by Kahanec and Zaiceva (2009), who compare the role of nativity and citizenship in old and new EU member states and show that it is foreign origin that is the key factor in Western Europe, whereas in Central-Eastern Europe (CEE), both foreign origin and citizenship result in substantial labour market gaps.

The higher incidence of precarious employment observed among immigrants may arise from a variety of factors, including labour market rigidities that tend to favour insiders over outsiders. Dustmann and Frattini (2011) point to the role of institutions, reporting that in countries with stricter employment protection legislation, the occupational distribution of immigrants is different to that of the natives, particularly for immigrants from outside the EU-15. The authors explain that in countries with higher employment protection, access to particular occupations is more difficult for immigrants, while the probability of employment is not associated with the protection legislation. D'Amuri and Peri (2010) confirm that

\footnotetext{
${ }^{6}$ EU-12 refers to the EU member states that joined the EU in 2004 and 2007. EU-15 refers to the pre-2004 EU member states.
} 
immigrants push natives into occupations with higher skill contents in Europe, and that the reallocation is more intense in less protected markets. The authors conclude that a high degree of labour market protection reduces labour markets' ability to absorb immigrants through occupational upgrading of natives.

The labour market status of immigrants is shown to be more sensitive to the business cycle than that of natives. Dustmann, Glitz and Vogel (2010) find that the unemployment probabilities of immigrants in Germany and the UK are significantly more sensitive to the economic cycle than those of natives, even after conditioning for individual characteristics and the region of residence. De la Rica and Polonyankina (2013) explain how recently arrived immigrants displaced earlier immigrants during the recession years in Spain. They also demonstrate a negative impact of competition for jobs during the Great Recession. Specifically, for 2008-2012, the authors show that relative to natives, immigrants in Spain moved into jobs characterized by higher manual content, such as those requiring finger dexterity, body coordination and strength.

The evidence of discrimination against immigrants is based on their differential treatment in the labour market compared to natives with the same qualifications (e.g., lower callback rates in response to submitted job applications). An edited volume by Kahanec and Zimmermann (2011) maps the social and labour market situation of ethnic minorities in Europe and demonstrates that immigrant and ethnic minority groups are often disadvantaged by unobservable factors such as gaps in social or ethnic capital, but also discrimination. Kahanec and Zaiceva (2009) report that while immigrants and non-citizens may possess sociodemographic characteristics that are superior to those possessed by native populations in the labour market, unobserved factors, such as discrimination, disadvantage them significantly. Kahanec, Kim and Zimmermann (2013) map the barriers to immigrant inclusion in the European labour markets and welfare systems: language barriers and human capital gaps, problematic recognition of foreign qualifications, unequal treatment, lack of transparency in the labour market and legal barriers. 


\section{Post-enlargement migration and the Great Recession}

Following the EU enlargements of 2004 and 2007, the gradual extension of the right of free movement of workers enabled many citizens from new EU member states to seek employment in the old EU member states. As a consequence, the inflows of workers from CEE to Western European countries have risen significantly since 2004, although the trend declined sharply during the crisis (Kahanec, 2013). Zaiceva and Zimmermann (2008) evaluate the scale, diversity and determinants of labour migration in Europe and observe different patterns of migration into EU-15 countries. Cultural, linguistic and geographical distances between pairs of source and destination countries are found to be an important determinant of migration inflows. While Poland was the main sending country to most of the EU-15 countries, Estonians are dominant in Finland, and Romanians in Spain and Italy. Because these new migrants' decision to leave their own countries is for the most part driven by employment considerations, and because typical barriers to mobility such as visa or residence and work permits do not constrain their mobility within the EU (after the expiration of transitional arrangements wherever they were applied), these new migrant populations are quite fluid and able to respond to changing economic conditions (Pytlikova, 2014; Kahanec et al., 2016).

The Great Recession had profound impacts on the world economy, with significant consequences for European economies. It adversely affected labour markets, causing unemployment to increase rapidly across Europe. If immigrant workers encounter disadvantages in the labour market, these may remain latent in better times, but they become acute during economic downturns when jobs are destroyed and the competition for jobs intensifies. On the other hand, as immigrants from the EU-12 tend to be skilled and young (Kahanec, 2013), they may more easily move to alternative destinations within Europe; one could thus expect them to be relatively resilient to the crisis.

However, a recent OECD SOPEMI report (2013) shows that the recent downturn has had a substantial negative impact on the labour force and especially on foreign-born persons. The report uses individual EU-LFS data to descriptively compare the employment, unemployment and long-term unemployment trends of native and immigrant workers. The findings suggest that young and low-skilled migrants were among the most affected, while the performance of 
women and high-skilled migrants was less affected during the recession. Voicu and Vlase (2012) use three waves of the European Social Survey to confirm that high-skilled immigrants exhibited a higher ability to keep paid employment during the recent crisis relative to medium- and low-skilled immigrants. However, the authors show as well that the high-skilled immigrants had lower odds of obtaining employment as compared to high-skilled natives, and that these differences were amplified during the economic downturn.

The OECD report further finds that a large share of the job losses was concentrated among those with temporary and fixed-term contracts and among those working in construction and manufacturing - in other words, in types of jobs and sectors with a high concentration of migrants. On the other hand, the services sector in Europe has recorded the greatest increases in migrant employment, given that many new jobs were created in 'residential care activities', 'activities of households as employers of domestic personnel' and 'human health services'. The balance of the effects of being a migrant in the enlarged EU during the Great Recession is thus an empirical question, which we will investigate in the next section.

\section{Measuring migrant-native gaps}

In the analysis of labour market gaps between natives and migrants from new EU member states, we employ the Blinder (1973) and Oaxaca (1973) counterfactual decomposition technique to study mean outcome differences between these groups. Non-linear regression models are applied to decompose the difference in an outcome variable between two groups native and immigrant population - into a part that is attributed to differences in characteristics (interpreted as an explained component that does not imply any treatment or behavioural disparities in the labour market ${ }^{7}$ ) and an unexplained component that arises due to behavioural or treatment inequalities between observably equal workers in the labour market.

We adapt the framework to represent two groups, native (n) and migrant (m) individuals characterized by two relationships

\footnotetext{
${ }^{7}$ However, sociodemographic differences of this type may result from inequalities arising outside the labour market.
} 


$$
\begin{aligned}
& Y_{n}=\alpha_{n}+X_{n}^{\prime} \beta_{n}+\varepsilon_{n} \\
& Y_{m}=\alpha_{m}+X_{m}^{\prime} \beta_{m}+\varepsilon_{m},
\end{aligned}
$$

where $\mathrm{Y}$ is the outcome variable; $\mathrm{X}$ is the vector of individual characteristics; $\alpha$ and $\beta$ are the intercept and the vector of coefficients, respectively; $\varepsilon$ is an error term; and subscripts $m$ and $n$ denote migrants and natives, respectively. Each regression model also includes country dummies. In order to examine the sources of outcome differences between natives and migrants, a counterfactual equation is constructed where migrants are treated as natives. In other words, the intercept and coefficient in the migrants' equation are replaced by those of the natives' equation. The counterfactual outcome $\bar{Y}_{m}^{*}$ is defined as

$$
\bar{Y}_{m}^{*}=\hat{\alpha}_{n}+\bar{X}_{m}^{\prime} \hat{\beta}_{n}
$$

The average gap between natives and migrants can be decomposed into a characteristics effect, that is, differences between natives' outcome and counterfactual outcome, and a coefficients effect, that is, differences between counterfactual outcome and migrants' outcome. ${ }^{8}$ The Blinder-Oaxaca decomposition equation is

$$
\bar{Y}_{n}-\bar{Y}_{m}=\left(\bar{X}_{n}-\bar{X}_{m}\right)^{\prime} \hat{\beta}_{n}+\bar{X}_{m}{ }^{\prime}\left(\hat{\beta}_{n}-\hat{\beta}_{m}\right)
$$

where $\bar{X}_{n}$ and $\bar{X}_{m}$ are vectors including the means of the variables for natives and migrants, respectively, and $\hat{\beta}_{n}$ and $\hat{\beta}_{m}$ are estimated coefficients from regressions (1) and (2). The first term of equation (4) on the right-hand side is the part of the gap due to different (average) characteristics of natives and migrants, while the second term is the part of the differential due to different coefficients that identifies differences in treatment or behaviour of otherwise comparable migrant and native workers. It is this latter term that measures migrant-native cleavages that cannot be explained by observable differences between migrants and natives. The analysis can also be performed with a binary dependent variable following the adapted non-linear decomposition described in Yun (2004) for studying differentials in variables such as participation, employment or unemployment.

\footnotetext{
${ }^{8}$ An important assumption in Oaxaca's approach is that labour supply and individual characteristics are fixed and would not respond to the changes in the outcome variable that would result from the elimination of discrimination.
} 


\section{Data and sample characteristics}

The European Union Labour Force Survey (EU-LFS) covering a representative sample of households in all EU member states is the main source of data for this study. The national statistical offices of each member country are responsible for data collection in accordance with a harmonized methodology. The EU-LFS collects information on respondents' personal circumstances (including nationality and country of birth) and their labour market status during a reference period of one to four weeks immediately prior to the interview. Because the sampling structure of the EU-LFS focuses strongly on permanent residents, it is likely to omit short-term and seasonal migration. The survey collects several work characteristics of employed individuals that are useful for assessing the quality of employment over time. Unfortunately, the EU-LFS does not include information on the income status of households.

Owing to its large sample size, the EU-LFS provides reliable information on the share of immigrant population in a country and it is commonly used in research on immigration in the European context (see, e.g., Huber et al., 2010; Dustmann and Frattini, 2011; D’Amuri and Peri, 2010). In this study, the terms 'immigrant population' or 'immigrant individuals' are used in the broad context of immigration, and the origin of immigrants is based on the country of birth. One exception is Germany, for which immigrant origin can be determined only by nationality. The EU-LFS allows us to concentrate on the situation of immigrants from the EU12 countries and contrast their performance with native workforces in the EU-15 countries. The final sample used in this study covers the period 2004-2011 and includes individuals of working age (15-65 years) in the EU-15, which amounts to more than 5.6 million individuals. ${ }^{9}$

Worker mobility from EU-12 to EU-15 after the EU's eastern enlargements exhibits several noteworthy patterns. Figure 5.1 plots the stock of migrants from EU-12 and EU-15 origins in the working-age population separately in the 15 old EU member states. The data show that EU-12 migrants were relatively scarce prior to the 2004 enlargement. While the stock of EU15 migrants remained stable at $2.4 \%$ during the period studied, the stock of EU-12 migrants more than tripled from $0.5 \%$ in 2004 to $1.7 \%$ in 2011 . The steepest increase of EU-12

\footnotetext{
${ }^{9}$ The sample includes Austria, Belgium, Denmark, Finland, France, Germany, Greece, Ireland, Italy, Luxembourg, the Netherlands, Portugal, Spain, Sweden and the United Kingdom.
} 
migrants is observed in the UK and Ireland, which fully opened their labour markets to EU-12 immigrants immediately after their countries' EU accession. The flow of EU-12 immigrants to Italy and Greece accelerated particularly after 2007 when Bulgaria and Romania joined the EU.

Figure 5.1. The share of immigrant population from EU-15 and EU-12 in the 15 old EU member states (as \% of the population)

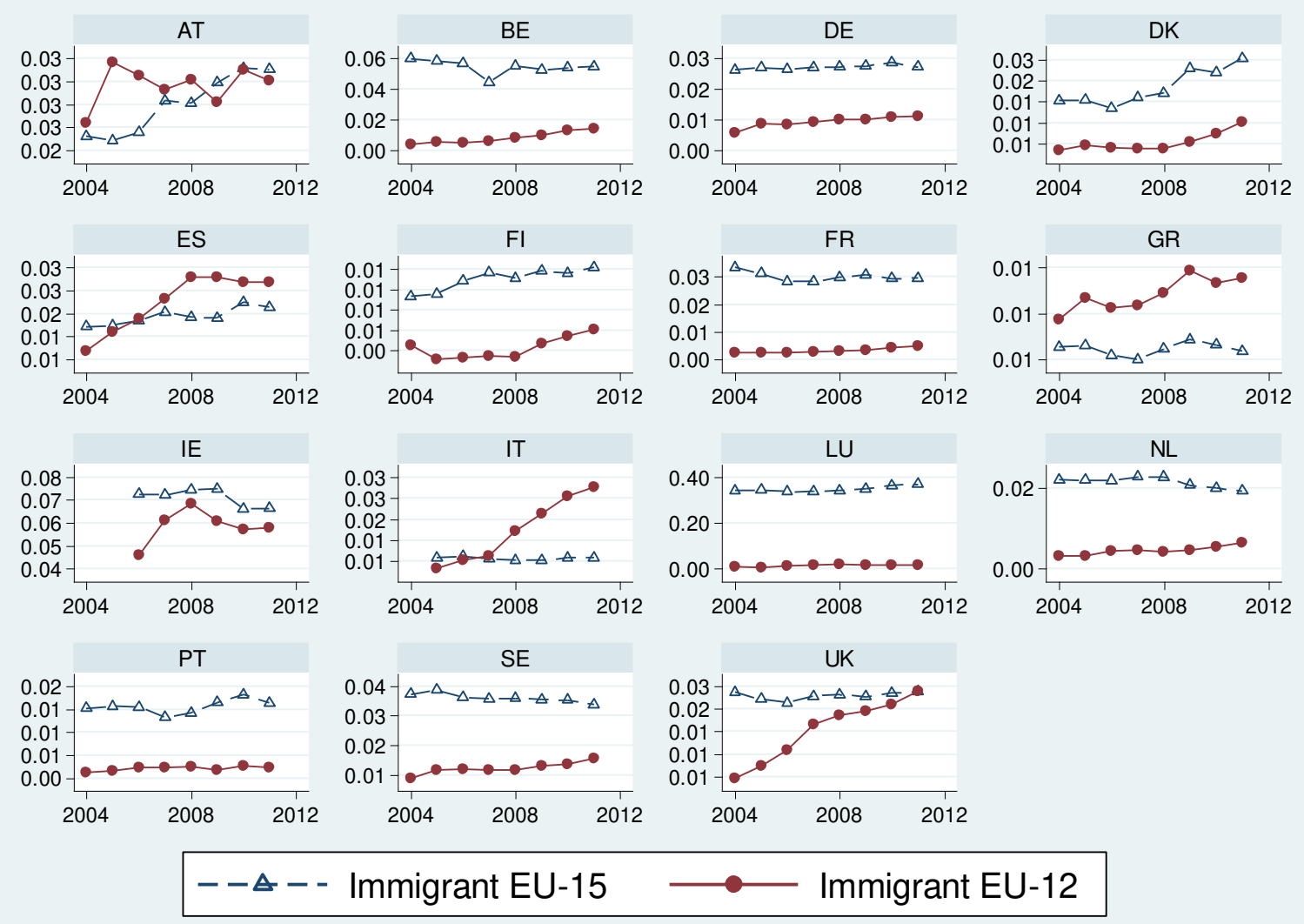

Source: EU-LFS, 2004-2011. Note: The origin of immigrants is determined by their country of birth, except for Germany, where immigrants are distinguished by their nationality. The sample is limited to individuals aged $15-65$ and is weighted by personal weights.

The outbreak of the crisis in the late 2000s had a visible negative effect on migration flows in countries greatly affected by the economic crisis, such as Ireland and Spain. ${ }^{10}$ In other

\footnotetext{
${ }^{10}$ In 2011, Spain reintroduced transitional arrangements that restricted Romanians' access to its labour market. These restrictions lasted until the end of 2013.
} 
countries, the stock of EU-12 immigrants remained constant or continued to grow after 2008 despite the crisis. Interestingly, the Scandinavian countries became a destination for EU-12 immigrants only after 2008, which may be explained by the relatively favourable economic conditions in these countries during the economic downturn. In 2011, immigrants from EU-12 countries made up about $13 \%$ of the entire population of foreign residents in EU-15. Although mobility slowed down in Europe during the crisis, based on observed patterns it appears that not too many migrants returned home as a consequence of the economic crisis. This does not come as a surprise, given that the employment opportunities in the EU-15 countries also remained more favourable during the crisis than the alternatives in migrants' home countries.

Table 5.1 compares the characteristics of EU-12 migrants with the native population in EU-15 in the sample. The numbers show that, on average, the migrant group is younger and includes a higher percentage of women and comparatively fewer highly educated individuals than natives, and also that about half of the migrants are concentrated in densely populated urban areas. A comparison of education characteristics reveals that approximately $80 \%$ of migrants attain at least upper secondary education (compared to $74 \%$ of natives), while $25 \%$ attain at least tertiary education (compared to $29 \%$ of natives). ${ }^{11}$

Table 5.1. Descriptive characteristics of EU-12 migrants and EU-15 native populations (mean values)

\begin{tabular}{lccc}
\hline Individual characteristics & Migrants & Natives & Diff \\
Female & 0.53 & 0.48 & 0.05 \\
Age & 35.6 & 40.1 & -4.49 \\
ISCED1 primary & 0.05 & 0.06 & -0.01 \\
ISCED2 lower secondary & 0.16 & 0.20 & -0.03 \\
ISCED3 upper secondary & 0.47 & 0.41 & 0.06 \\
ISCED4 post secondary & 0.06 & 0.04 & 0.02 \\
ISCED5 university & 0.25 & 0.29 & -0.05 \\
Urbanization: Densely populated area & 0.51 & 0.44 & 0.07 \\
Urbanization: Intermediate area & 0.20 & 0.29 & -0.09 \\
Urbanization: Thinly populated area & 0.29 & 0.27 & 0.02 \\
\hline Source: EU-LFS 2004 2011.
\end{tabular}
Source: EU-LFS 2004-2011.

\footnotetext{
${ }^{11}$ The variable 'highest qualification achieved' is coded in each country according to the International Standard Classification of Education (ISCED). The use of this classification may lead to difficulties in cross-country comparisons if ISCED does not adequately reflect the educational system of all countries. We consider this to be a minor problem since our analysis includes migrants from European countries in which ISCED is commonly used.
} 
To study the labour market situation of EU-12 migrants in EU-15 countries, we construct a set of indicators regarding the labour market outcomes of migrant and native populations: (i) labour force participation; (ii) unemployment; (iii) self-employment; and three indicators for job quality measured in terms of (iv) over-education; (v) low-skill employment; and (vi) type of contract (see Table 5.2). The data show that while migrants exhibit a higher labour market participation rate than natives, they also suffer from a higher unemployment rate. The immigrant-native participation gap remained relatively stable during the period studied, while the unemployment gap increased substantially during the Great Recession. Migrants exhibit an almost three times higher incidence of low-skill jobs and a two times higher incidence of over-qualification compared to natives. In general, they are less likely to be self-employed and more likely be employed on temporary contracts.

Table 5.2. Labour market indicators for EU-12 migrants and EU-15 natives over time

\begin{tabular}{lcccccccc}
\hline Outcome variables & Migrants & \multicolumn{7}{c}{ Natives } \\
& $2006-07$ & $2008-09$ & $2010-11$ & Total & $2006-07$ & $2008-09$ & $2010-11$ & Total \\
& 0.792 & 0.787 & 0.784 & 0.779 & 0.709 & 0.717 & 0.718 & 0.713 \\
Participation rate & 0.085 & 0.120 & 0.155 & 0.124 & 0.062 & 0.071 & 0.091 & 0.075 \\
Unempl. rate & 0.081 & 0.097 & 0.097 & 0.093 & 0.156 & 0.155 & 0.151 & 0.152 \\
Self-employment & 0.360 & 0.369 & 0.368 & 0.359 & 0.161 & 0.169 & 0.171 & 0.162 \\
Over-education & 0.275 & 0.271 & 0.299 & 0.280 & 0.099 & 0.095 & 0.092 & 0.096 \\
Low-skill job & & & & & & & & \\
Temporary & 0.232 & 0.207 & 0.199 & 0.219 & 0.144 & 0.140 & 0.144 & 0.143 \\
contract & & & & & & &
\end{tabular}

Source: EU-LFS 2004-2011.

\section{Migrant-native cleavages: Empirical evidence}

Do the raw gaps reported in the previous section reflect a disparate composition of migrant and native populations, or are they reflected in the labour market cleavages as an artefact of unequal treatment of otherwise equal individuals? We address these questions by decomposing immigrant-native raw gaps into the part that is due to differences in the characteristics of immigrant and native population and the part that arises due to factors other than the observed differences. We look at migrant-native cleavages in the areas of labour force participation and in the incidence of unemployment, self-employment, over-education, low-skill employment and temporary contracts. The gaps in the outcome variables between 
immigrant and native populations are decomposed into a part explained by differences in observed characteristics (i.e., the explained part) and a part attributable to differences in the estimated coefficients or unobserved factors (i.e., the unexplained part). The compositional differences of the immigrant and native workforces are measured in terms of age, education, gender and the degree of regional urbanization.

\section{Figure 5.2. Labour market participation of EU-15 natives and EU-12 immigrants}
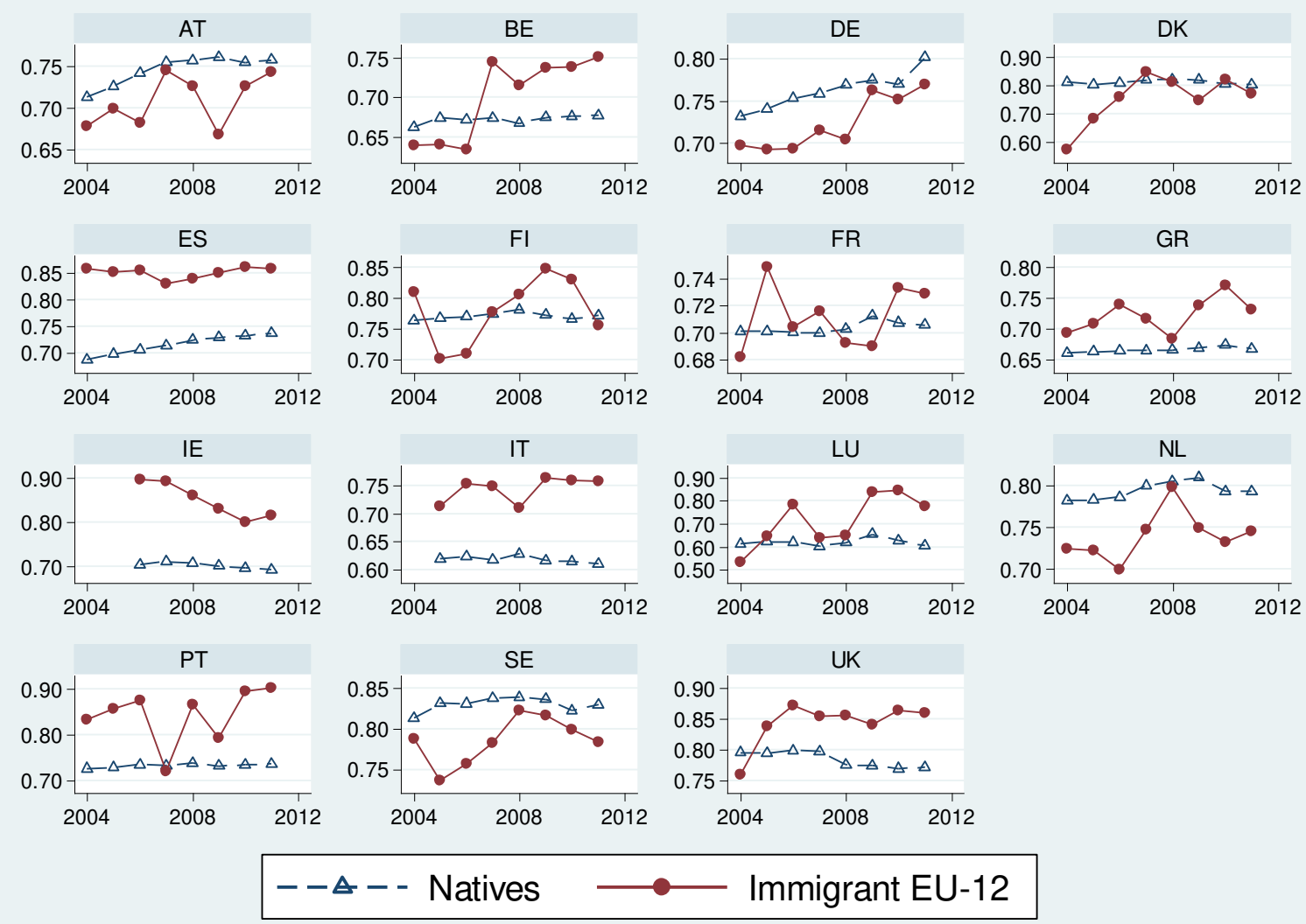

Source: EU-LFS 2004-2011. See notes to Figure 5.1. Following the International Labour Organization's definition of unemployment, labour market participation rate refers to the number of people who are either employed or are actively looking for work.

\section{Labour market participation}

Given that the post-enlargement migration flows to the EU-15 from CEE countries were predominantly driven by better employment prospects (Kahanec and Zimmermann, 2010, Kahanec et al., 2014; Pytlikova, 2014), the participation of EU-12 immigrants in the labour market can be expected to be high. Following the International Labour Organization's 
definition, labour market participation rate refers to the number of people who are either employed or are actively looking for and can take a job, relative to the working-age population. Figure 5.2 depicts unconditional differences in the participation rates between EU-12 immigrants and natives across countries and over time. It shows that the participation rates of immigrants are visibly higher than those of the natives in the countries where the inflows are largest, that is, in Southern Europe, the UK and Ireland. In the continental Europe and Nordic countries, the participation rates of EU-12 migrants are broadly comparable and in several of them are improving with respect to those of the natives. The figure shows that the participation of the immigrant workforce also remained robust during the crisis period, thus confirming the strong attachment of migrant workforces to the labour market.

Table 5.3. Decomposition results: Labour market participation rate

\begin{tabular}{|c|c|c|c|c|c|c|c|c|c|c|c|c|c|c|c|c|}
\hline & $\begin{array}{l}2004 \\
\mathrm{~b} / \mathrm{se}\end{array}$ & & $\begin{array}{l}2005 \\
\mathrm{~b} / \mathrm{se}\end{array}$ & & $\begin{array}{l}2006 \\
\mathrm{~b} / \mathrm{se}\end{array}$ & & $\begin{array}{l}2007 \\
\mathrm{~b} / \mathrm{se}\end{array}$ & & $\begin{array}{l}2008 \\
\mathrm{~b} / \mathrm{se}\end{array}$ & & $\begin{array}{l}2009 \\
\mathrm{~b} / \mathrm{se}\end{array}$ & & $\begin{array}{l}2010 \\
\mathrm{~b} / \mathrm{se}\end{array}$ & & $\begin{array}{l}2011 \\
\mathrm{~b} / \mathrm{se}\end{array}$ & \\
\hline $\mathrm{N}$ & $\begin{array}{c}0.727 \\
(0.007)\end{array}$ & $*$ & $\begin{array}{c}0.728 \\
(0.007)\end{array}$ & $*$ & $\begin{array}{c}0.777 \\
(0.005)\end{array}$ & * & $\begin{array}{c}0.796 \\
(0.004)\end{array}$ & $* * *$ & $\begin{array}{c}0.787 \\
(0.004)\end{array}$ & $*$ & $\begin{array}{c}0.787 \\
(0.004)\end{array}$ & ** & $\begin{array}{c}0.789 \\
(0.004)\end{array}$ & $* *$ & $\begin{array}{c}0.786 \\
(0.004)\end{array}$ & $* * *$ \\
\hline Nati & $\begin{array}{c}0.724 \\
(0.001)\end{array}$ & $* * *$ & $\begin{array}{c}0.708 \\
(0.001)\end{array}$ & $*$ & $\begin{array}{c}0.713 \\
(0.001)\end{array}$ & $*$ & $\begin{array}{c}0.718 \\
(0.001)\end{array}$ & $* *$ & $\begin{array}{c}0.721 \\
(0.001)\end{array}$ & * & $\begin{array}{c}0.721 \\
(0.001)\end{array}$ & $k *$ & $\begin{array}{c}0.719 \\
(0.001)\end{array}$ & $k *$ & $\begin{array}{c}0.725 \\
(0.001)\end{array}$ & $*$ \\
\hline dif & $\begin{array}{c}0.003 \\
(0.007)\end{array}$ & & $\begin{array}{c}0.021 \\
(0.007)\end{array}$ & * & $\begin{array}{c}0.065 \\
(0.005)\end{array}$ & $* * *$ & $\begin{array}{c}0.077 \\
(0.005)\end{array}$ & . & $\begin{array}{c}0.066 \\
(0.004)\end{array}$ & $* * *$ & $\begin{array}{c}0.065 \\
(0.004)\end{array}$ & $* *$ & $\begin{array}{c}0.07 \\
(0.004)\end{array}$ & $* *$ & $\begin{array}{c}0.061 \\
(0.004)\end{array}$ & $* *$ \\
\hline & $\begin{array}{c}0.026 \\
(0.003)\end{array}$ & $*$ & $\begin{array}{c}0.031 \\
(0.003)\end{array}$ & $* * *$ & $\begin{array}{c}0.049 \\
(0.002)\end{array}$ & $* * *$ & $\begin{array}{c}0.048 \\
(0.002)\end{array}$ & ** & $\begin{array}{c}0.046 \\
(0.002)\end{array}$ & $* * *$ & $\begin{array}{c}0.039 \\
(0.002)\end{array}$ & $* * *$ & $\begin{array}{c}0.035 \\
(0.002)\end{array}$ & $* * *$ & $\begin{array}{c}0.03 \\
(0.002)\end{array}$ & k* \\
\hline un & $\begin{array}{l}-0.023 \\
(0.007)\end{array}$ & $* * *$ & $\begin{array}{l}-0.01 \\
(0.006)\end{array}$ & $*$ & $\begin{array}{c}0.015 \\
(0.005)\end{array}$ & $* * *$ & $\begin{array}{c}0.03 \\
(0.004)\end{array}$ & $* * *$ & $\begin{array}{c}0.02 \\
(0.004)\end{array}$ & $* * *$ & $\begin{array}{c}0.026 \\
(0.004)\end{array}$ & $* * *$ & $\begin{array}{c}0.035 \\
(0.004)\end{array}$ & $* * *$ & $\begin{array}{c}0.031 \\
(0.004)\end{array}$ & $* * *$ \\
\hline & 708,031 & & 670,125 & & 724,92 & & 725,41 & & 702,500 & & 692,233 & & 710,287 & & 696,302 & \\
\hline N_Migra & 3,749 & & 4,308 & & 6,285 & & 7,699 & & 8,502 & & 8,878 & & 10,035 & & 10,976 & \\
\hline N_Native & 704,282 & & 665,817 & & 718,639 & & 717,718 & & 693,998 & & 683,355 & & 700,252 & & 685,326 & \\
\hline
\end{tabular}

Source: EU-LFS 2004-2011.

The decomposition analysis reported in Table 5.3 reveals that whereas the participation gap between EU-12 migrants and natives was small and insignificant in 2004, it steadily increased to as high as 7.7 percentage points in favour of migrants in 2007, levelling off at around 6 to 7 percentage points since then. About 3 to 5 percentage points of the gap are explained by differences in observable characteristics. Whereas unobserved factors disadvantaged migrants in 2004, the disadvantage disappeared in 2005 and turned into an advantage of around 2 to 4 percentage points in the subsequent years. A possible interpretation is that pre-enlargement migrants (observed in 2004) were somewhat positively selected on observable characteristics, but unobservable factors nullified this advantage. The observed pattern is consistent with the notion that the extension of the freedom of movement to citizens from the new EU member states allowed for a stronger positive selection in terms of observable and especially 
unobservable characteristics, yielding a positive participation premium overall. It could also be that following the EU 2004 and 2007 enlargements, the barriers to EU-12 citizens' participation diminished and that this enabled them to realize their potential in the receiving labour markets, as measured by the unexplained part of the participation differential.

\section{Unemployment}

During economic downturns, immigrant workers are often the first to lose their jobs, also because they are frequently employed in sectors that are particularly vulnerable to economic shocks (OECD, 2013). Figure 5.3 shows that migrants clearly have a higher risk of unemployment compared to natives in all countries except Greece, Portugal and the UK. After the outbreak of the economic crisis in the late 2000s, the unemployment rates of migrants increased sharply compared to natives in several countries, while in other countries both groups were equally affected (Greece), affected only a little (Luxembourg) or the migrant population was less affected (UK). The pattern is confirmed in the decomposition analysis (Table 5.4), which shows that in the period before the crisis, the immigrant-native unemployment differential decreased, but that the increase in unemployment rates during the crisis was much more pronounced for immigrants. Whereas the pre-crisis gap and its decline are mainly due to unobserved factors, deteriorations in the observed characteristics as well as unobserved factors contributed to the increase in the gap during the crisis.

Table 5.4. Decomposition results: Unemployment rate

\begin{tabular}{|c|c|c|c|c|c|c|c|c|c|c|c|c|c|c|c|c|}
\hline & $\begin{array}{l}2004 \\
\mathrm{~b} / \mathrm{se}\end{array}$ & & $\begin{array}{l}2005 \\
\mathrm{~b} / \mathrm{se}\end{array}$ & & $\begin{array}{l}2006 \\
\mathrm{~b} / \mathrm{se}\end{array}$ & & $\begin{array}{l}2007 \\
\mathrm{~b} / \mathrm{se}\end{array}$ & & $\begin{array}{l}2008 \\
\mathrm{~b} / \mathrm{se}\end{array}$ & & $\begin{array}{l}2009 \\
\mathrm{~b} / \mathrm{se}\end{array}$ & & $\begin{array}{l}2010 \\
\mathrm{~b} / \mathrm{se}\end{array}$ & & $\begin{array}{l}2011 \\
\mathrm{~b} / \mathrm{se}\end{array}$ & \\
\hline Migrant & $\begin{array}{c}0.125 \\
(0.006)\end{array}$ & $* * *$ & $\begin{array}{c}0.123 \\
(0.006)\end{array}$ & $* * *$ & $\begin{array}{c}0.090 \\
(0.004)\end{array}$ & $* * *$ & $\begin{array}{c}0.086 \\
(0.004)\end{array}$ & $* * *$ & $\begin{array}{c}0.093 \\
(0.004)\end{array}$ & $* * *$ & $\begin{array}{c}0.145 \\
(0.004)\end{array}$ & $* * *$ & $\begin{array}{c}0.155 \\
(0.004)\end{array}$ & $* * *$ & $\begin{array}{c}0.152 \\
(0.004)\end{array}$ & $* * *$ \\
\hline Native & $\begin{array}{c}0.079 \\
(0.000)\end{array}$ & $* * *$ & $\begin{array}{c}0.073 \\
(0.000)\end{array}$ & $* * *$ & $\begin{array}{c}0.065 \\
(0.000)\end{array}$ & $* * *$ & $\begin{array}{c}0.058 \\
(0.000)\end{array}$ & $* * *$ & $\begin{array}{c}0.059 \\
(0.000)\end{array}$ & $* * *$ & $\begin{array}{c}0.082 \\
(0.000)\end{array}$ & $* * *$ & $\begin{array}{c}0.091 \\
(0.000)\end{array}$ & $* * *$ & $\begin{array}{c}0.091 \\
(0.000)\end{array}$ & $* * *$ \\
\hline difference & $\begin{array}{c}0.046 \\
(0.006)\end{array}$ & $* * *$ & $\begin{array}{c}0.050 \\
(0.006)\end{array}$ & $* * *$ & $\begin{array}{c}0.025 \\
(0.004)\end{array}$ & $* * *$ & $\begin{array}{c}0.028 \\
(0.004)\end{array}$ & $* * *$ & $\begin{array}{c}0.033 \\
(0.004)\end{array}$ & $* * *$ & $\begin{array}{c}0.064 \\
(0.004)\end{array}$ & $* * *$ & $\begin{array}{c}0.065 \\
(0.004)\end{array}$ & $* * *$ & $\begin{array}{c}0.061 \\
(0.004)\end{array}$ & $* * *$ \\
\hline explained & $\begin{array}{c}0.006 \\
(0.001)\end{array}$ & $* * *$ & $\begin{array}{c}0.012 \\
(0.001)\end{array}$ & $* * *$ & $\begin{array}{c}0.005 \\
(0.001)\end{array}$ & $* * *$ & $\begin{array}{c}0.008 \\
(0.001)\end{array}$ & $* * *$ & $\begin{array}{c}0.015 \\
(0.001)\end{array}$ & $* * *$ & $\begin{array}{c}0.037 \\
(0.001)\end{array}$ & $* * *$ & $\begin{array}{c}0.033 \\
(0.001)\end{array}$ & $* * *$ & $\begin{array}{c}0.031 \\
(0.001)\end{array}$ & $* * *$ \\
\hline unexplained & $\begin{array}{c}0.040 \\
(0.006)\end{array}$ & $* * *$ & $\begin{array}{c}0.037 \\
(0.005)\end{array}$ & $* * *$ & $\begin{array}{c}0.020 \\
(0.004)\end{array}$ & $* * *$ & $\begin{array}{c}0.020 \\
(0.003)\end{array}$ & $* * *$ & $\begin{array}{c}0.019 \\
(0.003)\end{array}$ & $* * *$ & $\begin{array}{c}0.026 \\
(0.004)\end{array}$ & $* * *$ & $\begin{array}{c}0.032 \\
(0.004)\end{array}$ & $* * *$ & $\begin{array}{c}0.030 \\
(0.003)\end{array}$ & $* * *$ \\
\hline Total & 512,435 & & 473,956 & & 516,729 & & 521,534 & & 506,892 & & 499,803 & & 511,563 & & 505,416 & \\
\hline Migrant & 2,700 & & 3,139 & & 4,859 & & 6,122 & & 6,684 & & 6,979 & & 7,918 & & 8,620 & \\
\hline Native & 509,735 & & 470,817 & & 511,870 & & 515,412 & & 500,208 & & 492,824 & & 503,645 & & 496,796 & \\
\hline
\end{tabular}

Source: EU-LFS 2004-2011. 
Figure 5.3. Unemployment rates of EU-15 natives and EU-12 immigrants
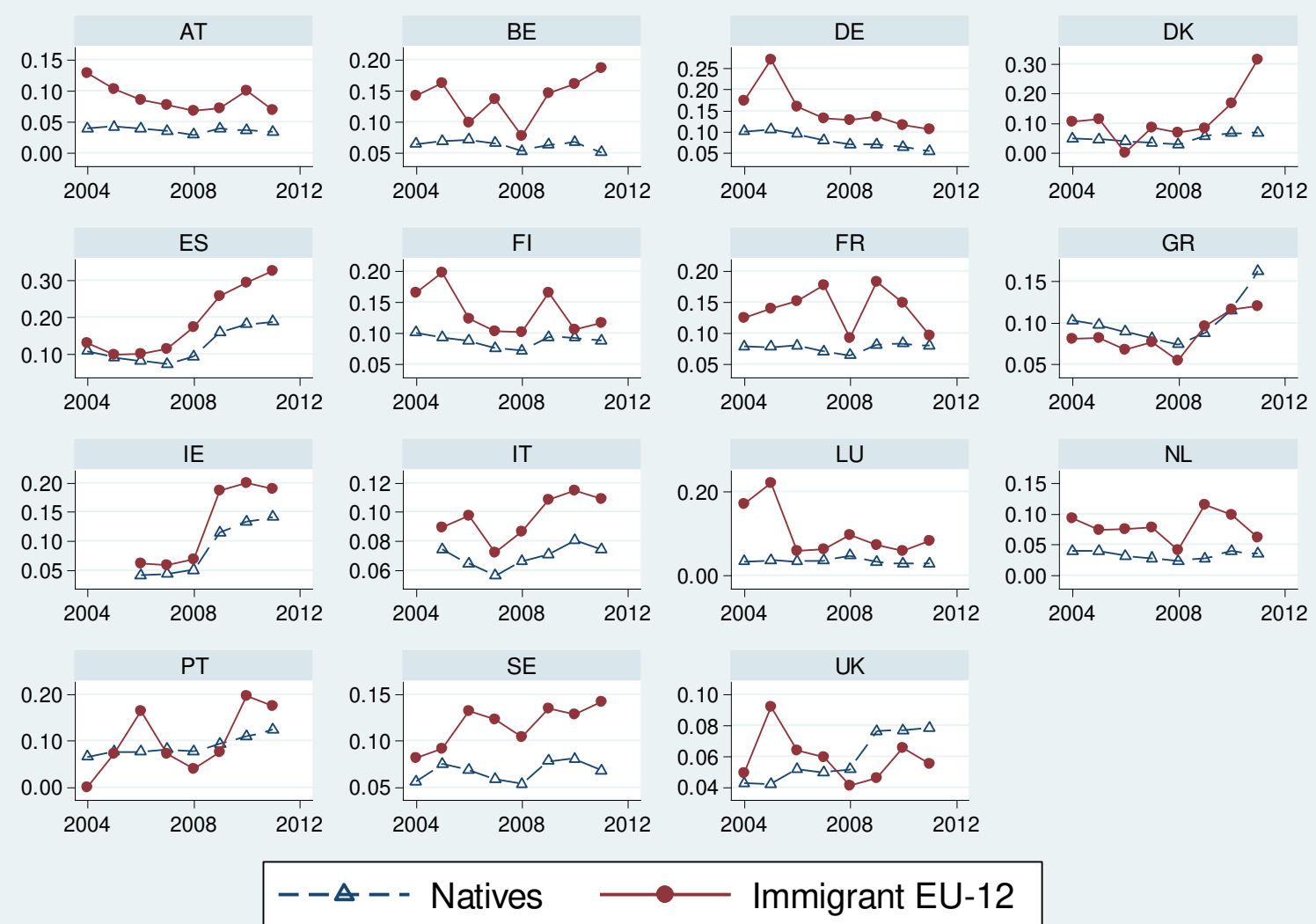

Source: EU-LFS 2004-2011.

\section{Self-employment}

As shown above, during the Great Recession the risk of unemployment increased more for immigrants than for natives in many countries. The immigrant-native gap in the selfemployment rate shows the inverse of the gap in unemployment rates. This countercyclical nature of the self-employment gap, although not very pronounced, is reflected in an increasing immigrant-native self-employment gap before the crisis and a diminishing gap since its outbreak. This indicates that during periods of job scarcity, self-employment may provide an alternative form of employment especially for migrants. For example, if a scarcity of jobs leads to heightened discrimination of immigrants by employers, self-employment may be a way of avoiding such situations. ${ }^{12}$ Alternatively, it may be that during the downturn,

\footnotetext{
${ }^{12}$ It may also be that self-employment provided a way to circumvent transitional arrangements restricting access of EU-12 workers to EU-15 labor markets (but not restricting the free movement of services and hence the selfemployed). Gradual opening of labor markets would imply a decreasing self-employment rate over time for
} 
companies employing migrants put additional pressure on their workers to adopt selfemployed status in order to save on wage-related costs, which, according to the conceptualization developed by Bernaciak in the Introduction to this volume, would constitute social dumping. One should note as well that throughout the observed period, the rate of selfemployment was lower among immigrants than within the native labour force. Between $20 \%$ to $48 \%$ of the immigrant-native gap in self-employment rates is explained by differences in the observable characteristics included in the analysis (Table 5.5). Whereas the explained as well as the unexplained parts peak in 2006, the explained part fades away by 2011, but the role of the unexplained part increases in 2010 and dominates in 2011.

Table 5.5. Decomposition results: Self-employment rate

\begin{tabular}{|c|c|c|c|c|c|c|c|c|c|c|c|c|c|c|c|c|}
\hline & $\begin{array}{l}2004 \\
\mathrm{~b} / \mathrm{se}\end{array}$ & & $\begin{array}{l}2005 \\
\mathrm{~b} / \mathrm{se}\end{array}$ & & $\begin{array}{l}2006 \\
\mathrm{~b} / \mathrm{se}\end{array}$ & & $\begin{array}{l}2007 \\
\mathrm{~b} / \mathrm{se}\end{array}$ & & $\begin{array}{l}2008 \\
\mathrm{~b} / \mathrm{se}\end{array}$ & & $\begin{array}{l}2009 \\
\mathrm{~b} / \mathrm{se}\end{array}$ & & $\begin{array}{l}2010 \\
\mathrm{~b} / \mathrm{se}\end{array}$ & & $\begin{array}{l}2011 \\
\mathrm{~b} / \mathrm{se}\end{array}$ & \\
\hline Migrant & $\begin{array}{c}0.088 \\
(0.006)\end{array}$ & $* * *$ & $\begin{array}{c}0.107 \\
(0.006)\end{array}$ & $* * *$ & $\begin{array}{c}0.087 \\
(0.004)\end{array}$ & $* * *$ & $\begin{array}{c}0.089 \\
(0.004)\end{array}$ & $* * *$ & $\begin{array}{c}0.096 \\
(0.004)\end{array}$ & $* * *$ & $\begin{array}{c}0.106 \\
(0.004)\end{array}$ & $* * *$ & $\begin{array}{c}0.101 \\
(0.004)\end{array}$ & $* * *$ & $\begin{array}{c}0.098 \\
(0.003)\end{array}$ & $* * *$ \\
\hline Native & $\begin{array}{c}0.137 \\
(0.000)\end{array}$ & $* * *$ & $\begin{array}{c}0.157 \\
(0.001)\end{array}$ & $* * *$ & $\begin{array}{c}0.157 \\
(0.001)\end{array}$ & $* * *$ & $\begin{array}{c}0.155 \\
(0.001)\end{array}$ & $* * *$ & $\begin{array}{c}0.156 \\
(0.001)\end{array}$ & $* * *$ & $\begin{array}{c}0.154 \\
(0.001)\end{array}$ & $* * *$ & $\begin{array}{c}0.153 \\
(0.001)\end{array}$ & $* * *$ & $\begin{array}{c}0.150 \\
(0.001)\end{array}$ & $* * *$ \\
\hline difference & $\begin{array}{c}-0.048 \\
(0.006)\end{array}$ & $* * *$ & $\begin{array}{l}-0.051 \\
(0.006)\end{array}$ & $* * *$ & $\begin{array}{l}-0.070 \\
(0.005)\end{array}$ & $* * *$ & $\begin{array}{l}-0.067 \\
(0.004)\end{array}$ & $* * *$ & $\begin{array}{l}-0.061 \\
(0.004)\end{array}$ & $* * *$ & $\begin{array}{l}-0.048 \\
(0.004)\end{array}$ & $* * *$ & $\begin{array}{l}-0.051 \\
(0.004)\end{array}$ & $* * *$ & $\begin{array}{c}-0.052 \\
(0.004)\end{array}$ & $* * *$ \\
\hline explained & $\begin{array}{l}-0.013 \\
(0.002)\end{array}$ & $* * *$ & $\begin{array}{l}-0.021 \\
(0.002)\end{array}$ & $* * *$ & $\begin{array}{l}-0.027 \\
(0.001)\end{array}$ & $* * *$ & $\begin{array}{l}-0.027 \\
(0.001)\end{array}$ & $* * *$ & $\begin{array}{l}-0.025 \\
(0.001)\end{array}$ & $* * *$ & $\begin{array}{l}-0.021 \\
(0.001)\end{array}$ & $* * *$ & $\begin{array}{l}-0.015 \\
(0.001)\end{array}$ & $* * *$ & $\begin{array}{l}-0.009 \\
(0.001)\end{array}$ & $* * *$ \\
\hline unexplained & $\begin{array}{l}-0.036 \\
(0.006)\end{array}$ & $* * *$ & $\begin{array}{l}-0.030 \\
(0.007)\end{array}$ & $* * *$ & $\begin{array}{l}-0.043 \\
(0.005)\end{array}$ & $* * *$ & $\begin{array}{l}-0.040 \\
(0.005)\end{array}$ & $* * *$ & $\begin{array}{l}-0.036 \\
(0.004)\end{array}$ & $* * *$ & $\begin{array}{l}-0.027 \\
(0.005)\end{array}$ & $* * *$ & $\begin{array}{l}-0.036 \\
(0.004)\end{array}$ & $* * *$ & $\begin{array}{c}-0.044 \\
(0.004)\end{array}$ & $* * *$ \\
\hline Total & 471,667 & & 439,205 & & 483,140 & & 490,779 & & 476,396 & & 458,332 & & 464,534 & & 458,818 & \\
\hline Migrant & 2,387 & & 2,753 & & 4,448 & & 5,593 & & 6,061 & & 5,963 & & 6,686 & & 7,308 & \\
\hline Native & 469,280 & & 436,452 & & 478,692 & & 485,186 & & 470,335 & & 452,369 & & 457,848 & & 451,510 & \\
\hline
\end{tabular}

Source: EU-LFS 2004-2011.

\section{Quality of employment}

During economic downturns, the probability of finding a job is reduced, so the incentives to take a lower-quality job can be relatively higher. This may be especially true for migrants for several reasons. Unemployed migrants have limited access to the social safety net in the host (or home) country, and the earnings opportunities in low-skilled jobs may be acceptable with respect to the income standards in their home countries. In addition, immigrants have strong incentives to work in order to be able to support household members left in their home country. These factors could reduce migrants' reservation wages and channel them to lowerquality employment vis-à-vis the natives. We restrict the sample to employed individuals and

EU-12 workers in EU-15, and hence diminishing self-employment gap. The outbreak of crisis however slowed the process and even reverted the trend. 
decompose the gap observed in working conditions such as the incidence of over-education, employment in low-skilled occupations and temporary contracts.

\section{a. Over-education}

The match between qualifications and jobs is an important measure for evaluating the performance of highly skilled workers in the labour market. In general, as argued by Huber et al. (2010), highly skilled migrants are more likely to occupy jobs under their level of education relative to the native workforce. The main reasons arise from differences between home- and host-country education systems, the lack of formal recognition of skills abroad or the lack of specific human capital (such as language skills or knowledge of labour market institutions), and various forms of discrimination. We construct a simple indicator of overeducation to evaluate the skill-matching of workers following the method of realized matches. . Based on occupational codes (two-digit ISCO), in each occupational group we identify the level of education of the median worker, distinguishing between low, medium and high educational level. All workers in the same occupational group with a higher education than the median worker are then marked as over-educated. The identification of over-educated workers is done separately for each country to account for country-specific differences. The high incidence of qualification mismatch should be interpreted with caution because occupations are not a perfect proxy for job requirements.

Table 5.6. Decomposition results: Incidence of over-education among workers

\begin{tabular}{|c|c|c|c|c|c|c|c|c|c|c|c|c|c|c|c|c|}
\hline & $\begin{array}{l}2004 \\
\mathrm{~b} / \mathrm{se}\end{array}$ & & $\begin{array}{l}2005 \\
\mathrm{~b} / \mathrm{se}\end{array}$ & & $\begin{array}{l}2006 \\
\mathrm{~b} / \mathrm{se}\end{array}$ & & $\begin{array}{l}2007 \\
\mathrm{~b} / \mathrm{se}\end{array}$ & & $\begin{array}{l}2008 \\
\text { b/se }\end{array}$ & & $\begin{array}{l}2009 \\
\mathrm{~b} / \mathrm{se}\end{array}$ & & $\begin{array}{l}2010 \\
\mathrm{~b} / \mathrm{se}\end{array}$ & & $\begin{array}{l}2011 \\
\mathrm{~b} / \mathrm{se}\end{array}$ & \\
\hline $\mathrm{N}$ & $\begin{array}{c}0.318 \\
(0.015)\end{array}$ & $* * *$ & $\begin{array}{c}0.377 \\
(0.011)\end{array}$ & $* * *$ & $\begin{array}{c}0.392 \\
(0.010)\end{array}$ & $* * *$ & $\begin{array}{c}0.419 \\
(0.009)\end{array}$ & $* * *$ & $\begin{array}{c}0.407 \\
(0.008)\end{array}$ & $* * *$ & $\begin{array}{c}0.427 \\
(0.009)\end{array}$ & $* * *$ & $\begin{array}{c}0.420 \\
(0.008)\end{array}$ & * & $\begin{array}{c}0.453 \\
(0.008)\end{array}$ & \\
\hline Nati & $\begin{array}{c}0.178 \\
(0.001)\end{array}$ & $* * *$ & $\begin{array}{c}0.201 \\
(0.001)\end{array}$ & $* * *$ & $\begin{array}{c}0.201 \\
(0.001)\end{array}$ & $* * *$ & $\begin{array}{c}0.206 \\
(0.001)\end{array}$ & $*$ & $\begin{array}{c}0.209 \\
(0.001)\end{array}$ & $* * *$ & $\begin{array}{c}0.214 \\
(0.001)\end{array}$ & $*$ & $\begin{array}{c}0.218 \\
(0.001)\end{array}$ & $* * *$ & $\begin{array}{c}0.207 \\
(0.001)\end{array}$ & * \\
\hline dif & $\begin{array}{c}0.140 \\
(0.015)\end{array}$ & $* * *$ & $\begin{array}{c}0.176 \\
(0.012)\end{array}$ & $* * *$ & $\begin{array}{c}0.190 \\
(0.010)\end{array}$ & $* * *$ & $\begin{array}{c}0.213 \\
(0.009)\end{array}$ & $* * *$ & $\begin{array}{c}0.197 \\
(0.008)\end{array}$ & $* * *$ & $\begin{array}{c}0.212 \\
(0.009)\end{array}$ & $* * *$ & $\begin{array}{c}0.202 \\
(0.008)\end{array}$ & $* * *$ & $\begin{array}{c}0.247 \\
(0.008)\end{array}$ & $* *$ \\
\hline expla & $\begin{array}{l}-0.007 \\
(0.010)\end{array}$ & & $\begin{array}{l}-0.010 \\
(0.011)\end{array}$ & & $\begin{array}{l}-0.000 \\
(0.009)\end{array}$ & & $\begin{array}{l}-0.002 \\
(0.008)\end{array}$ & & $\begin{array}{l}-0.006 \\
(0.007)\end{array}$ & & $\begin{array}{l}-0.004 \\
(0.008)\end{array}$ & & $\begin{array}{l}-0.012 \\
(0.007)\end{array}$ & $*$ & $\begin{array}{c}0.004 \\
(0.007)\end{array}$ & \\
\hline unexp & $\begin{array}{c}0.147 \\
(0.006)\end{array}$ & $* * *$ & $\begin{array}{c}0.186 \\
(0.007)\end{array}$ & $* * *$ & $\begin{array}{c}0.190 \\
(0.006)\end{array}$ & $* * *$ & $\begin{array}{l}0.215 \\
(0.005)\end{array}$ & $* * *$ & $\begin{array}{c}0.204 \\
(0.005)\end{array}$ & $* * *$ & $\begin{array}{c}0.217 \\
(0.005)\end{array}$ & $* * *$ & $\begin{array}{c}0.214 \\
(0.005)\end{array}$ & $* * *$ & $\begin{array}{c}0.243 \\
(0.005)\end{array}$ & $* * *$ \\
\hline & 386,467 & & 346,981 & & 381,210 & & 389,089 & & 380,201 & & 367,775 & & 376,220 & & 371,187 & \\
\hline Migrant & 2,030 & & 2,333 & & 3,826 & & 4,756 & & 5,220 & & 5,002 & & 5,531 & & 5,863 & \\
\hline Native & 84,437 & & 344,648 & & 377,384 & & 384,333 & & 374,981 & & 362,773 & & 370,689 & & 365,324 & \\
\hline
\end{tabular}

Source: EU-LFS 2004-2011.

Our findings suggest that highly skilled migrants face substantial difficulties in transferring skills across borders. Migrants exhibit an almost two times higher risk of over-education in 
their labour market position relative to natives. The results of the decomposition analysis reported in Table 5.6 reveal that the substantial part of the gap in over-education between immigrant and native workers is not explained by observable characteristics, which in fact work in favour of migrants. An important implication is that migrants accept jobs below their educational level mainly in relation to unobservable factors. A possible explanation is that over-education emerges due to the low language ability or more generally due to the low transferability of the unobserved skills of migrants. Our results further indicate that the incidence of over-education has increased especially among immigrants, and that most of the increase took place before the crisis, primarily due to a steep increase in the unexplained part of the differential. As those were the years of significantly increased east-west migration, this latter finding appears to underscore the importance of immigrant adjustment and imperfect skill transferability. Some qualification mismatch is likely to be explained by issues other than skills discrepancies, such as the skill heterogeneity among workers with the same qualifications.

\section{b. Low-skilled jobs}

Our results show that the high incidence of over-education among immigrant workers goes hand in hand with their concentration in the lowest-skill occupations. This outcome is confirmed by the share of migrant workers employed in the elementary occupations characterized by simple and routine tasks (ISCO group 9). Our findings reported in Table 5.7 show that immigrants are three times more likely to be employed in the elementary occupations compared to natives and that the gap cannot be explained by differences in observable characteristics. After 2008, the incidence of taking a low-skill job increased for immigrants, while the opposite pattern is observed for native workers. A tentative explanation would be that immigrant workers who cannot access the welfare system are more likely to accept low-skill jobs when the competition for jobs becomes tense, while the native workforce has more opportunities available to avoid lowest-skill employment, including drawing unemployment benefits, entering early retirement or inactivity, or relying on other sources of household income. The decomposition analysis confirms that employment in the low-skill occupations is almost exclusively due to the unobserved characteristics of migrants. 
Table 5.7. Decomposition results: Incidence of elementary occupation

\begin{tabular}{|c|c|c|c|c|c|c|c|c|c|c|c|c|c|c|c|c|}
\hline & $\begin{array}{l}2004 \\
\mathrm{~b} / \mathrm{se}\end{array}$ & & $\begin{array}{l}2005 \\
\mathrm{~b} / \mathrm{se}\end{array}$ & & $\begin{array}{l}2006 \\
\mathrm{~b} / \mathrm{se}\end{array}$ & & $\begin{array}{l}2007 \\
\mathrm{~b} / \mathrm{se}\end{array}$ & & $\begin{array}{l}2008 \\
\mathrm{~b} / \mathrm{se}\end{array}$ & & $\begin{array}{l}2009 \\
\mathrm{~b} / \mathrm{se}\end{array}$ & & $\begin{array}{l}2010 \\
\mathrm{~b} / \mathrm{se}\end{array}$ & & $\begin{array}{l}2011 \\
\mathrm{~b} / \mathrm{se}\end{array}$ & \\
\hline $\bar{M}$ & $\begin{array}{c}0.232 \\
(0.009)\end{array}$ & $* * *$ & $\begin{array}{c}0.249 \\
(0.008)\end{array}$ & $* * *$ & $\begin{array}{c}0.256 \\
(0.007)\end{array}$ & $* * *$ & $\begin{array}{c}0.266 \\
(0.006)\end{array}$ & $*$ & $\begin{array}{c}0.250 \\
(0.006)\end{array}$ & * & $\begin{array}{c}0.262 \\
(0.006)\end{array}$ & $* * *$ & $\begin{array}{c}0.285 \\
(0.006)\end{array}$ & * & $\begin{array}{c}0.282 \\
(0.005)\end{array}$ & \\
\hline $\mathrm{N}$ & $\begin{array}{c}0.085 \\
(0.000)\end{array}$ & $* * *$ & $\begin{array}{c}0.088 \\
(0.000)\end{array}$ & $* * *$ & $\begin{array}{c}0.088 \\
(0.000)\end{array}$ & $* * *$ & $\begin{array}{c}0.087 \\
(0.000)\end{array}$ & $*$ & $\begin{array}{c}0.085 \\
(0.000)\end{array}$ & * & $\begin{array}{c}0.083 \\
(0.000)\end{array}$ & * & $\begin{array}{c}0.083 \\
(0.000)\end{array}$ & $* *$ & $\begin{array}{c}0.079 \\
(0.000)\end{array}$ & * \\
\hline $\mathrm{di}$ & $\begin{array}{c}0.147 \\
(0.009)\end{array}$ & $* * *$ & $\begin{array}{c}0.161 \\
(0.008)\end{array}$ & $* * *$ & $\begin{array}{c}0.168 \\
(0.007)\end{array}$ & $* * *$ & $\begin{array}{c}0.179 \\
(0.006)\end{array}$ & $* * *$ & $\begin{array}{c}0.164 \\
(0.006)\end{array}$ & $*$ & $\begin{array}{c}0.178 \\
(0.006)\end{array}$ & $* * *$ & $\begin{array}{c}0.201 \\
(0.006)\end{array}$ & $* *$ & $\begin{array}{c}0.203 \\
(0.005)\end{array}$ & * \\
\hline ex & $\begin{array}{l}-0.017 \\
(0.003)\end{array}$ & $* * *$ & $\begin{array}{l}-0.013 \\
(0.003)\end{array}$ & $* * *$ & $\begin{array}{l}-0.015 \\
(0.002)\end{array}$ & $* * *$ & $\begin{array}{l}-0.005 \\
(0.002)\end{array}$ & ** & $\begin{array}{l}-0.009 \\
(0.002)\end{array}$ & $* * *$ & $\begin{array}{l}-0.005 \\
(0.002)\end{array}$ & $* *$ & $\begin{array}{c}0.006 \\
(0.002)\end{array}$ & $* * *$ & $\begin{array}{c}0.013 \\
(0.002)\end{array}$ & $* * *$ \\
\hline unex & $\begin{array}{c}0.164 \\
(0.009)\end{array}$ & $* * *$ & $\begin{array}{c}0.174 \\
(0.008)\end{array}$ & $* * *$ & $\begin{array}{c}0.183 \\
(0.007)\end{array}$ & $* * *$ & $\begin{array}{c}0.184 \\
(0.006)\end{array}$ & $* * *$ & $\begin{array}{c}0.173 \\
(0.006)\end{array}$ & $* * *$ & $\begin{array}{c}0.184 \\
(0.006)\end{array}$ & $* * *$ & $\begin{array}{c}0.195 \\
(0.005)\end{array}$ & $* * *$ & $\begin{array}{c}0.189 \\
(0.005)\end{array}$ & $* * *$ \\
\hline & 471,8 & & 439,362 & & 483,265 & & 490,869 & & 476,518 & & 458,437 & & 464,694 & & 458,918 & \\
\hline Migrant & 2,389 & & 2,754 & & 4,449 & & 5,567 & & 6,065 & & 5,930 & & 6,688 & & 7,309 & \\
\hline Native & 469,430 & & 436,608 & & 478,816 & & 485,302 & & 470,453 & & 452,507 & & 458,006 & & 451,609 & \\
\hline
\end{tabular}

Source: EU-LFS 2004-2011.

Table 5.8. Decomposition results: Temporary contracts

\begin{tabular}{|c|c|c|c|c|c|c|c|c|c|c|c|c|c|c|c|c|}
\hline & $\begin{array}{l}2004 \\
\mathrm{~b} / \mathrm{se}\end{array}$ & & $\begin{array}{l}2005 \\
\mathrm{~b} / \mathrm{se}\end{array}$ & & $\begin{array}{l}2006 \\
\mathrm{~b} / \mathrm{se}\end{array}$ & & $\begin{array}{l}2007 \\
\mathrm{~b} / \mathrm{se}\end{array}$ & & $\begin{array}{l}2008 \\
\mathrm{~b} / \mathrm{se}\end{array}$ & & $\begin{array}{l}2009 \\
\mathrm{~b} / \mathrm{se}\end{array}$ & & $\begin{array}{l}2010 \\
\mathrm{~b} / \mathrm{se}\end{array}$ & & $\begin{array}{l}2011 \\
\mathrm{~b} / \mathrm{se}\end{array}$ & \\
\hline Migrant & $\begin{array}{c}0.287 \\
(0.009)\end{array}$ & $* * *$ & $\begin{array}{c}0.270 \\
(0.009)\end{array}$ & $* * *$ & $\begin{array}{c}0.236 \\
(0.006)\end{array}$ & $* * *$ & $\begin{array}{c}0.232 \\
(0.006)\end{array}$ & $* * *$ & $\begin{array}{c}0.216 \\
(0.005)\end{array}$ & $* * *$ & $\begin{array}{c}0.198 \\
(0.005)\end{array}$ & $* * *$ & $\begin{array}{c}0.193 \\
(0.005)\end{array}$ & $* * *$ & $\begin{array}{c}0.204 \\
(0.005)\end{array}$ & $* * *$ \\
\hline Native & $\begin{array}{c}0.144 \\
(0.001)\end{array}$ & $* * *$ & $\begin{array}{c}0.146 \\
(0.001)\end{array}$ & $* * *$ & $\begin{array}{c}0.144 \\
(0.001)\end{array}$ & $* * *$ & $\begin{array}{c}0.147 \\
(0.001)\end{array}$ & $* * *$ & $\begin{array}{c}0.143 \\
(0.001)\end{array}$ & $* * *$ & $\begin{array}{c}0.136 \\
(0.001)\end{array}$ & $* * *$ & $\begin{array}{c}0.143 \\
(0.001)\end{array}$ & $* * *$ & $\begin{array}{c}0.146 \\
(0.001)\end{array}$ & *** \\
\hline difference & $\begin{array}{c}0.142 \\
(0.009)\end{array}$ & $* * *$ & $\begin{array}{c}0.125 \\
(0.009)\end{array}$ & $* * *$ & $\begin{array}{c}0.092 \\
(0.006)\end{array}$ & $* * *$ & $\begin{array}{c}0.085 \\
(0.006)\end{array}$ & $* * *$ & $\begin{array}{c}0.073 \\
(0.005)\end{array}$ & $* * *$ & $\begin{array}{c}0.062 \\
(0.005)\end{array}$ & $* * *$ & $\begin{array}{c}0.050 \\
(0.005)\end{array}$ & $* * *$ & $\begin{array}{c}0.058 \\
(0.005)\end{array}$ & $* * *$ \\
\hline explained & $\begin{array}{c}0.019 \\
(0.004)\end{array}$ & $* * *$ & $\begin{array}{c}0.019 \\
(0.004)\end{array}$ & $* * *$ & $\begin{array}{c}0.005 \\
(0.003)\end{array}$ & $*$ & $\begin{array}{c}0.009 \\
(0.002)\end{array}$ & $* * *$ & $\begin{array}{c}0.004 \\
(0.002)\end{array}$ & $*$ & $\begin{array}{c}0.007 \\
(0.002)\end{array}$ & $* * *$ & $\begin{array}{c}0.002 \\
(0.002)\end{array}$ & & $\begin{array}{c}0.003 \\
(0.002)\end{array}$ & \\
\hline unexplained & $\begin{array}{c}0.123 \\
(0.008)\end{array}$ & $* * *$ & $\begin{array}{c}0.106 \\
(0.008)\end{array}$ & $* * *$ & $\begin{array}{c}0.087 \\
(0.006)\end{array}$ & $* * *$ & $\begin{array}{c}0.076 \\
(0.005)\end{array}$ & $* * *$ & $\begin{array}{c}0.069 \\
(0.005)\end{array}$ & $* * *$ & $\begin{array}{c}0.055 \\
(0.005)\end{array}$ & $* * *$ & $\begin{array}{c}0.048 \\
(0.005)\end{array}$ & $* * *$ & $\begin{array}{c}0.055 \\
(0.005)\end{array}$ & **** \\
\hline Total & 398,713 & & 363,155 & & 400,731 & & 407,977 & & 395,720 & & 381,761 & & 388,243 & & 385,168 & \\
\hline Migrant & 2,153 & & 2,429 & & 4,026 & & 5,052 & & 5,428 & & 5,289 & & 5,954 & & 6,549 & \\
\hline Native & 396,560 & & 360,726 & & 396,705 & & 402,925 & & 390,292 & & 376,472 & & 382,289 & & 378,619 & \\
\hline
\end{tabular}

Source: EU-LFS 2004-2011.

\section{c. Type of contract}

We show above that immigrants have higher incidences of over-qualification and low-skill employment and a higher risk of unemployment. In addition, a higher prevalence of temporary contracts is noticeable among immigrants, although the share of immigrants with temporary contracts exhibits a declining trend and the native-immigrant gap is closing. Our results in Table 5.8 illustrate that only a small part of the immigrant-native gap defining the quality of employment is explained by workers' characteristics, a larger part being due to cleavages that cannot be explained by observable differences, which may be related to immigrants' disconnectedness from social networks, differences in ethnic capital or 
discrimination arising, for example, from employers' inclination to employ migrants on temporary contracts (also see Berntsen and Lillie, this volume).

\section{Conclusions}

This chapter studied the labour market position of EU-12 immigrants in the old EU member states after the EU enlargements of 2004 and 2007 and during the Great Recession. Using EU-LFS data and the Oaxaca-Blinder-Yun type of decomposition techniques, we show that although immigrant-native gaps can be partly explained by group differences in individual characteristics, there still exist significant migrant-native cleavages in EU labour markets that cannot be explained by observable factors and that are therefore due to other factors including differences in social or ethnic capital, language skills or discrimination.

Our results show a worrying trend of increased labour market gaps in most domains between EU-12 migrants and natives in old EU member states. The two exceptions among the outcome variables studied are self-employment, which exhibits steady gaps, and the incidence of temporary contracts, where the gaps declined during the period studied. Another important result is that these gaps can only partly be explained by observable characteristics such as age, gender or education. In most cases, a larger part of the gaps is due to unobserved factors. For labour market participation and unemployment, immigrant-native cleavages decreased after enlargement; however, the recent crisis slowed down these trends. Cleavages in selfemployment (which perhaps served as a second-best option for those who were unable to find waged employment or resulted from employees' or employers' efforts to minimize labour costs) exhibited patterns inverse to those we found for unemployment cleavages. As we expected, cleavages in the incidence of over-education and low-skilled employment grew in view of increased labour mobility in the early post-enlargement period but levelled off during the crisis. The unexplained gaps in temporary contracts decreased especially before the Great Recession.

The observed differences concerning the incidence of self-employment, low-skilled employment and temporary contracts might result from strategic behaviour on the part of migrant workers or their employers aimed at reducing the costs of labour. However, on the 
basis of the available statistical data, it is not possible to directly measure the extent of social dumping incentives and/or practices as discussed by Bernaciak in the Introduction of this volume, nor is it possible to establish a causal link between social dumping practices and the persistence of the above-mentioned cleavages.

The above limitation notwithstanding, the results of our study do suggest that Europe needs to do much more to facilitate and fully benefit from the free mobility of workers across its labour markets. In this respect, unexplained gaps measured in this chapter are of particular concern because they signify linguistic, social or ethnicity-related barriers, skill mismatches in the labour market (also including discrimination of migrants) or possible vulnerabilities of migrant workers resulting in their exclusion from quality employment and working conditions. These cleavages may undermine the social fabric in the receiving countries and lead to a vicious circle of negative attitudes and ill-chosen migration and integration policies. They may also spark even greater fears of social dumping in the future because these cleavages essentially imply lower quality of employment of otherwise equal migrants.

On the other hand, one needs to be careful when interpreting these cleavages. Mobility generally goes hand in hand with adjustment, which may be swift or sluggish, also depending on labour market institutions and policies. Migrants' choices matter, too. Temporary migrants may find it inefficient to invest in human capital specific to the receiving country if the costs of such investment are not compensated by higher earnings over a sufficiently long period of time. And yet, temporary and circular migrants may benefit from their migration experience, and mutual benefits in terms of better skill-matching and economic efficiency from such migration may also result for the receiving and the sending countries. And, finally, whenever the lack of adjustment results from institutional barriers to integration or unequal treatment of migrants, these and not migration as such are the primary sources of the migrant-native cleavages. Against this background, we can conclude that whereas the free mobility of labour is by and large a success story, especially when it comes to the benefits for Europe's labour markets, equal treatment of migrants and the elimination of barriers to migrants' social and labour market integration remain among the key policy challenges for the enlarged EU. 


\section{References}

Amuedo-Dorantes, C. and de la Rica, S. (2007) 'Labour Market Assimilation of Recent Immigrants in Spain'. British Journal of Industrial Relations, 45(2): 257-284.

Biavaschi, C. and Zimmermann, K. (2014) 'Eastern Partnership Migrants in Germany: Outcomes, Potentials and Challenges'. IZA Journal of European Labor Studies, 3:7 [Online]. Available at: http://www.izajoels.com/content/3/1/7 [Accessed 3 September 2014].

Blinder, A. S. (1973) 'Wage Discrimination: Reduced Form and Structural Estimates'. Journal of Human Resources, 8(4): 436-455.

Borjas, G. J. (1985) 'Assimilation, Changes in Cohort Quality, and the Earnings of Immigrants'. Journal of Labour Economics, 3(4): 463-489.

Chiswick, B. R. (1978) 'The Effect of Americanization on the Earnings of Foreign-born Men'. The Journal of Political Economy, 86(5): 897-921.

D’Amuri, F. and Peri, G. (2010) 'Immigration and Occupations in Europe'. CReAM Discussion Paper, no. 26/10. London: Centre for Research and Analysis of Migration.

De la Rica, S., Glitz, A. and Ortega, F. (2015) 'Immigration in Europe: Trends, Policies and Empirical Evidence'. In: Chiswick, B. R. and Miller, P. W. (eds.). Handbook of the Economics of International Migration, 1: 1303-1362, Amsterdam: Elsevier.

De la Rica, S. and Polonyankina, T. (2013) 'The Impact of Immigration on Occupational Specialisation among Natives in Spain: Does the Business Cycle Matter?' Revista de Economía Aplicada, 21(63): 51-74.

Dustmann, C. and Frattini, T. (2011) 'Immigration: The European Experience'. IZA Discussion Paper, no. 6261. Bonn: Institute for the Study of Labor. 
Dustmann, C., Glitz, A. and Vogel, T. (2010) 'Employment, Wages, and the Economic Cycle: Differences between Immigrants and Natives'. European Economic Review, 54(1): 1-17.

Dustmann, C. and Van Soest, A. (2002) 'Language and the Earnings of Immigrants'. Industrial and Labour Relations Review, 55(3): 473-492.

Entorf, H. and Minoiu, N. (2005) 'What a Difference Immigration Policy Makes: A Comparison of PISA Scores in Europe and Traditional Countries of Immigration'. German Economic Review, 6(3): 355-376.

Huber, P., Landesmann, M., Robinson, C. and Stehrer, R. (2010) 'Migrants' Skills and Productivity: A European Perspective'. National Institute Economic Review, 213(1): R20R34.

Kahanec, M. (2013) 'Labour Mobility in an Enlarged European Union’. In: Constant, A. F. and Zimmermann, K. F. (eds.). International Handbook on the Economics of Migration. Cheltenham: Edward Elgar, pp. 137-152.

Kahanec, M., Kim, A. M. and Zimmermann, K. F. (2013) 'Pitfalls of Immigrant Inclusion into the European Welfare State'. International Journal of Manpower, 34(1): 97-98.

Kahanec, M. and Shields, M. (2013) 'The Working Hours of Immigrants in Germany: Temporary versus Permanent'. IZA Journal of Migration, 2:14 [Online]. Available at: http://www.izajom.com/content/2/1/14 [Accessed 3 September 2014].

Kahanec, M. and Zaiceva, A. (2009) 'Labour Market Outcomes of Immigrants and Noncitizens in the EU: An East-West Comparison'. International Journal of Manpower, 30(1/2): 97-115.

Kahanec, M. and Zimmermann, K. F. (eds.) (2010) EU Labor Markets after Post-enlargement Migration. Berlin: Springer. 
Kahanec, M. and Zimmermann, K. F. (eds.) (2011) Ethnic Diversity in European Labour Markets: Challenges and Solutions. Cheltenham: Edward Elgar.

Kahanec, M., Pytliková, M. and Zimmermann, K. F. (2016) 'The Free Movement of Workers in an Enlarged European Union: Institutional Underpinnings of Economic Adjustment', in: M. Kahanec and K.F. Zimmermann (eds.), Labor Migration, EU Enlargement, and the Great Recession, Berlin: Springer Verlag

Marchetti, S., Piazzalunga, D. and Venturini, A. (2014) 'Does Italy Represent an Opportunity for Temporary Migrants from the Eastern Partnership Countries?' IZA Journal of European Labor Studies, 3:8 [Online]. Available at: http://www.izajoels.com/content/3/1/8 [Accessed 3 September 2014].

Oaxaca, R. (1973) 'Male-female Wage Differentials in Urban Labour Markets'. International Economic Review, 14(3): 693-709.

OECD (2013) International Migration Outlook: SOPEMI-2013. Paris: Organisation for Economic Co-operation and Development.

Pytliková, M. (2014) The effect of EU enlargements and labour market openings on migration, mimeo

Voicu, B. and Vlase, I. (2012) High-Skilled Immigrants and Social Integration in Times of Crisis. A Cross-European Analysis. Mimeo. Bucharest: Romanian Academy of Science, Research Institute for Quality of Life.

Yun, M.-S. (2004) 'Decomposing Differences in the First Moment'. Economics Letters, 82(2): 275-280.

Zaiceva, A. and Zimmermann, K. F. (2008) 'Scale, Diversity, and Determinants of Labour Migration in Europe'. Oxford Review of Economic Policy, 24(3): 427-451. 
Zaiceva, A. and Zimmermann, K. F. (2016) 'Returning Home at Times of Trouble? Return Migration of EU Enlargement Migrants during the Crisis'. in: M. Kahanec and K.F.

Zimmermann (eds.), Labor Migration, EU Enlargement, and the Great Recession, Berlin: Springer Verlag. 